\title{
Profile of Working-Age Patients with Keloid and Hypertrophic Scar at Dr. Soetomo General Hospital Surabaya in 2014-2017
}

\author{
Fania Ayu Wardani1 ${ }^{1}$, David Sontani Perdanakusuma ${ }^{2^{*}}$, Diah Mira Indramaya ${ }^{3}$
}

${ }^{1}$ Faculty of Medicine, Universitas Airlangga, Surabaya, Indonesia.

${ }^{2}$ Department of Plastic, Reconstructive, and Aesthetic Surgery, Faculty of Medicine, Universitas Airlangga/Dr. Soetomo General Hospital, Surabaya, Indonesia.

${ }^{3}$ Department of Dermatology and Venereology, Universitas Airlangga/Dr. Soetomo General Hospital, Surabaya, Indonesia.

\section{A B S T R A C T}

Introduction: Keloid and hypertrophic scar are pathological scars resulting from excessive accumulation of collagen in wound healing process. Data about profiles of keloid and hypertrophic scar are rarely found in Indonesia. Therefore, it is necessary to conduct research related to keloid and hypertrophic scar. This study aimed to provide valuable data for further research.

Methods: This was descriptive retrospective study evaluating 105 patients treated for keloid and hypertrophic scar from 2014 to 2017 using medical records of workingage patients.

Results: Mostly in patients between 17-25 years old (40\%). Comparison between male and female patients were 1.07:1 (keloid) and 1.09:1 (hypertrophic scar). As many as $10.71 \%$ of patients of keloid and $17.39 \%$ patients of hypertrophic scar were private employees. $23.21 \%$ patients with keloid and $23.91 \%$ patients of hypertrophic scar were Javanese. $14.29 \%$ patients of keloid and $19.57 \%$ patients of hypertrophic scar tend to have daily indoor activities. $17.86 \%$ patients of keloid and $26.09 \%$ patients of hypertrophic scar felt dark-skinned toned. Most keloid scars were caused by traumatic lesions (32.14\%), located on the chest $(19.54 \%)$, and treated by corticosteroid injection. Hypertrophic scar mostly caused by burn injury (54.35\%), located on the face $(29.55 \%)$, and treated by excision surgery.

Conclusion: Both keloid and hypertrophic scars were mostly developed in 17-25 years old, male, private employees, Javanese ethnic, dark skin tone patients, with daily indoor activities, caused by traumatic lesion and located on the chest, earlobe, and hand, treated by corticosteroid injection (keloid). Meanwhile, hypertrophic scars are mostly caused by a burn injury on the face and treated by excision surgery.

\section{*Correspondence: dperdanakusuma@gmail.com}

JUXTA: Jurnal IImiah Mahasiswa Kedokteran Universitas Airlangga

p-ISSN: 1907-3623; e-ISSN: 2684-9453

DOI: 10.20473/juxta.V12I22021.77-83

Open access under Creative Commons Attribution-ShareAlike 4.0 International License (CC-BY-SA)

\section{ARTICLE INFO}

Article history:

Received 01 June 2021

Received in revised form 10 July 2021

Accepted 6 August 2021

Available online 31 August 2021

\section{Keywords:}

Keloid,

Human \& disease,

Hypertrophic scar,

Pathological scar,

Working-age. 


\section{Introduction}

Based on the research results in Prof. Dr. R. D. Kandou Hospital, Manado, from January 2008 to December 2010, 61 patients with keloid were found, and 93 cases of keloid from 5550 cases of skin diseases were found from January 2011 to December $2015 .{ }^{1}$ While 63 out of 478 cases of benign skin tumor keloid were found from the research of benign skin tumors in the same hospital from 2009 to 2011,2 meanwhile in the United Kingdom, hypertrophic scar occurs in 23 million cases on postoperative patients. ${ }^{3}$ The prevalence of patients with the hypertrophic scar in Regional Public Hospital of dr. Slamet of Garut Regency was increased from 160 patients in 2013 to 200 patients in $2014 .^{4}$

Keloids and hypertrophic scars can develop anywhere on the body, but keloids mainly occur on the chest, upper arm, and scapular region, areas with high tension ${ }^{5}$ and also head, neck, shoulder, and ear lobe. ${ }^{6}$ Meanwhile, hypertrophic scars commonly occur on the shoulder, neck, presternum area, knee, and elbow. ${ }^{7}$

Some risk factors related to the occurrence of keloid and hypertrophic scar are age, ${ }^{8}$ anatomical site, genetic, and trauma, ${ }^{9}$ and also skin tone ${ }^{8}$ as well as skin tension. ${ }^{5}$ The incidence of both pathological scars according to gender tends to be similar. ${ }^{10}$ Based on the observational research on 30 cases of keloid in Dr. Soetomo General Hospital, Surabaya, $76.7 \%$ were women in the range of 10 30 years old. Meanwhile, according to the theory, the incidence of the keloid in dark people is 5 to 15 times higher than in white people. ${ }^{11}$ It shows that the darker someone's skin tone, the higher their tendency to develop a keloid. While the hypertrophic scar is less affected by the skin pigmentation. ${ }^{8}$

Until now, data about keloid and hypertrophic scar are rarely found in Indonesia. Based on this background, it is necessary to evaluate the profile of keloid patients and hypertrophic scar in the Department of Plastic, Reconstructive, and Aesthetic Surgery, Dr. Soetomo General Hospital Surabaya on 2014-2017, which is focused on working-age patients.

\section{Methods}

This research was a descriptive retrospective study using medical records of working-age patients in the Department of Plastic, Reconstructive, and Aesthetic Surgery, Dr. Soetomo General Hospital, Surabaya. Another method used was the interview method via phone.

Sampling method in this study used a consecutive technique based on inclusion criteria, which was the working-age patients who experienced the pathological scar when they were in the working-age range (15-64 years old) and not younger nor older. The variables were workingage, gender, ethnicity, occupation, and the tendency of outdoor or indoor daily activity, skin tones, location of lesions, tissue size, and treatment. The data obtained were inserted into Microsoft Excel and analyzed descriptively. The data presented in the form of tables and graphs.

\section{Results}

Table 1 shows that the overall keloid and hypertrophic scar patients in 2014-2017 in the Department of Plastic, Reconstructive, and Aesthetic Surgery Dr. Soetomo General Hospital Surabaya were 382 people. Total working-age patients were 295 patients, with 105 patients used in the study, and 28 of 105 patients were obtained through telephone interviews. The information about the patient's ethnicity, occupation, skin tone, and the tendency of indoor or outdoor activities was obtained by phone interview. The Fitzpatrick classification of skin tone is generally used, but this study only used the patient's opinion subjectively through the phone interview. Meanwhile, in the scar classification, the Vancouver Scar Scale is generally used, but this study only used the size of the scar stated in the medical records.

The highest number of patients who developed keloid was in 2014 with 23 patients, followed by 16 patients in 2016, 13 patients in 2015, and 4 patients in 2017. On the other hand, the highest to the lowest number of hypertrophic scar patients were in 2014 (19 patients), 2017 (10 patients), 2015 (9 patients), and 2016 (8 patients). Patients who developed both scars were found in 2015, 2016, and 2017.

Table 1. The distribution of the number of keloid and hypertrophic scar patients

\begin{tabular}{|c|c|c|c|c|c|}
\hline & 2014 & 2015 & 2016 & 2017 & Total \\
\hline Patients all age & 120 & 105 & 90 & 67 & 382 \\
\hline $\begin{array}{l}\text { Working-age } \\
\text { patients }\end{array}$ & 90 & 70 & 73 & 62 & 295 \\
\hline $\begin{array}{l}\text { Patients involved } \\
\text { in the study }\end{array}$ & 42 & 23 & 25 & 15 & 105 \\
\hline Keloid & 23 & 13 & 16 & 4 & 56 \\
\hline Hypertrophic scar & 19 & 9 & 8 & 10 & 46 \\
\hline Combination & 0 & 1 & 1 & 1 & 3 \\
\hline
\end{tabular}

\section{Demographic Aspect Data Working Age}

The distribution of the working age of keloid and hypertrophic scar patients was mainly at the age of 17-25 years old, while patients who developed both scars were 36-45 years old.

Table 2. The working-age distribution of patients with keloid, hypertrophic scar, and both scars

\begin{tabular}{cccccc}
\hline Age & Keloid & $\begin{array}{c}\text { Hypertrophic } \\
\text { scar }\end{array}$ & Both & Total & $\%$ \\
\hline $\mathbf{1 5 - 1 6}$ & 2 & 1 & 1 & 4 & 3.81 \\
$\mathbf{1 7 - 2 5}$ & 20 & 22 & 0 & 42 & 40 \\
$\mathbf{2 6 - 3 5}$ & 18 & 11 & 0 & 29 & 27.62 \\
$\mathbf{3 6 - 4 5}$ & 2 & 6 & 2 & 10 & 9.52 \\
\hline
\end{tabular}




\begin{tabular}{cccccc}
$\mathbf{4 6 - 5 5}$ & 11 & 5 & 0 & 16 & 15.24 \\
$\mathbf{5 6 - 6 4}$ & 3 & 1 & 0 & 4 & 3.81 \\
\hline Total & 56 & 46 & 3 & 105 & 100
\end{tabular}

with a percentage of $2.17 \%$ of 1 hypertrophic scar patient. On the other hand, the rest were unknown.

\section{Gender}

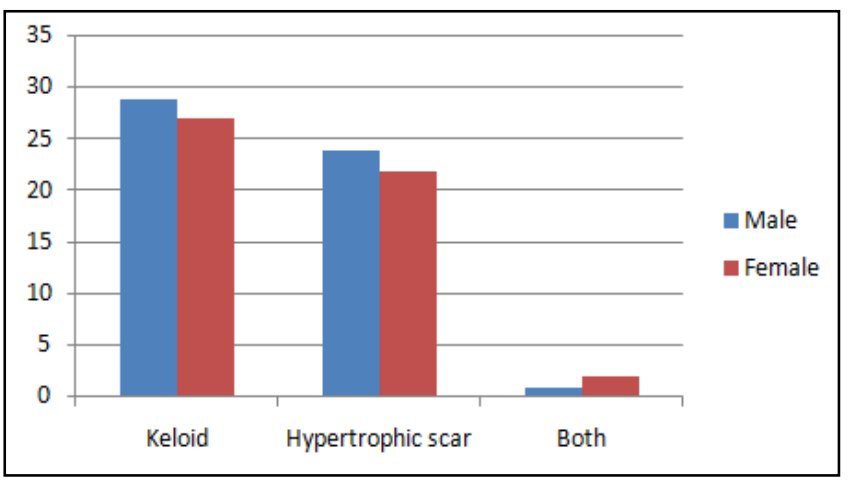

Figure 1. The gender distribution of working-age patients with keloid, hypertrophic scar, and both scars

Based on gender, patients who developed keloid and hypertrophic scar were mostly male patients with the ratio of male and female patients of 1.07:1 for keloid and 1.09:1 for the hypertrophic scar. Meanwhile, those who developed both scars were mostly female patients with the ratio of male and female patients of 1:2.

\section{Patient's Occupation}

The distribution of the patient's known occupation was dominated by 6 keloid patients $(10.71 \%)$ and 8 hypertrophic scar patients $(17.39 \%)$ as private employees, while the least occupation were 1 keloid patient $(1.79 \%)$ and 1 hypertrophic scar patient $(2.17 \%)$ as army/cops. Meanwhile, patients who experienced both scars were private employees, housewives, and students with the percentage of $33.33 \%$ in each occupation. Furthermore, the rest were unknown.

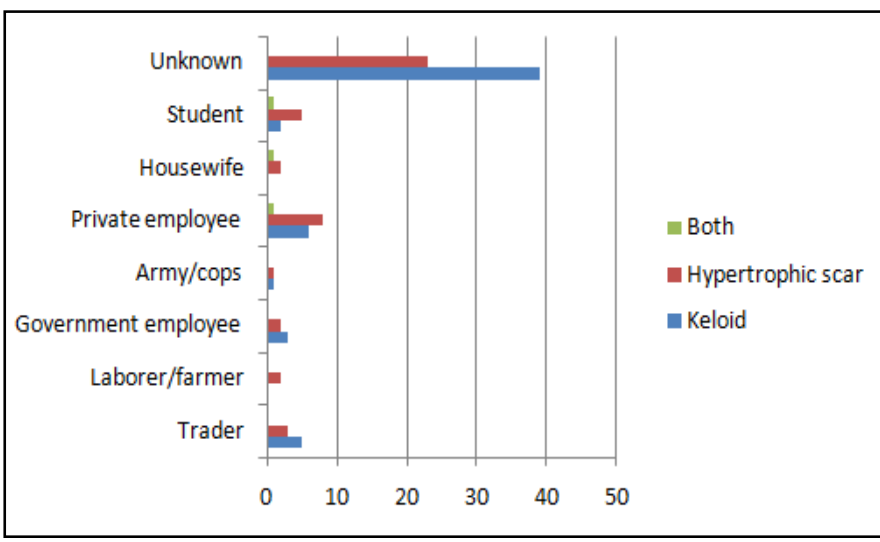

Figure 2. The distribution of patient's occupation of working-age patient with keloid, hypertrophic scar, and both scars

\section{Ethnicity}

The distribution of the patient's known ethnicity, obtained by phone interview, was dominated by Javanese 13 keloid patients $(23.21 \%), 11$ hypertrophic scar patients $(23.91 \%)$, and 2 patients who developed both scars $(66.67 \%)$. Meanwhile, the least ethnicity was in other categories that came from East Nusa Tenggara's region

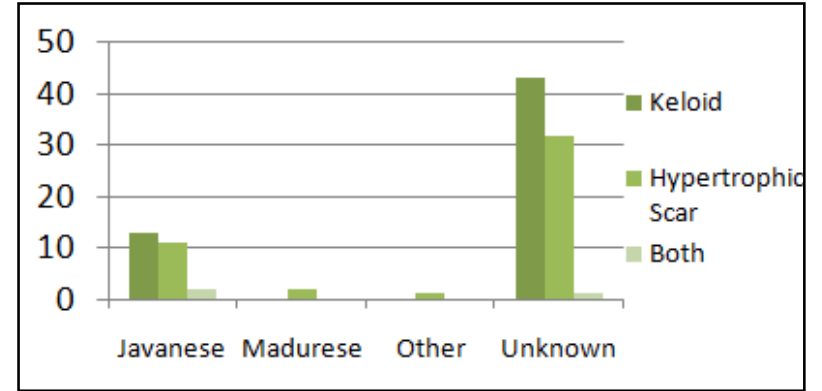

Figure 3. The distribution of working-age patient's ethnicity with keloid, hypertrophic scar, and both scars

\section{Tendency of Indoor and Outdoor Daily Activity}

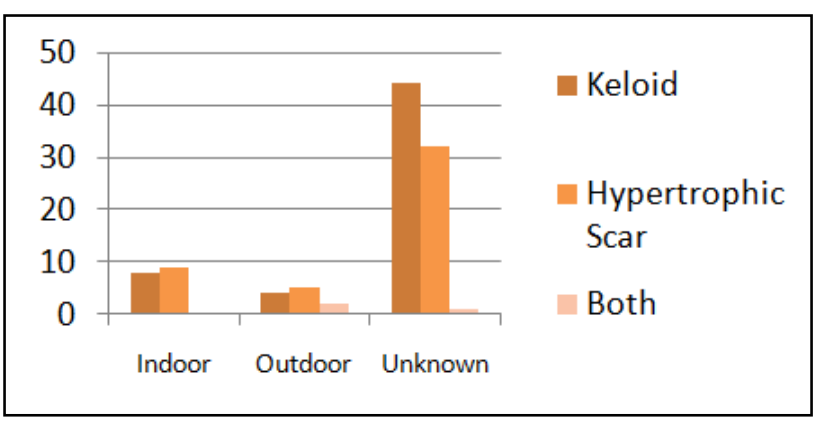

Figure 4. The distribution of working-age patient's daily activity with keloid, hypertrophic scar, and both scars

Figure 4 shows that patients who tend to have daily indoor activity dominate the data for 8 keloid patients (14.29\%) and 9 hypertrophic scar patients (19.57\%). Meanwhile, 2 out of 3 patients who developed both scars tended to have outdoor activities. The patients who could not be interviewed by phone were $78.57 \%$ of keloid patients, $69.57 \%$ of hypertrophic scar patients, and $33.33 \%$ of patients who developed both scars.

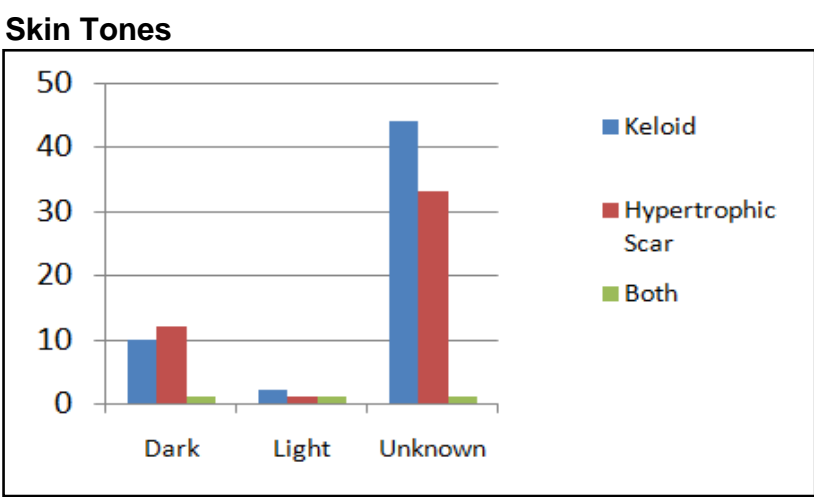

Figure 5. The distribution of patient's skin tones of workingage patient with keloid, hypertrophic scar, and both scars

Figure 5 shows that most keloid and hypertrophic scar were developed on patients who felt dark-skinned; they were 10 keloid patients (17.86\%) and 12 hypertrophic scar patients $(26.09 \%)$. The ratio of dark skin patients and light skin patients was 5:1 (keloid) and 12:1 (hypertrophic scar), respectively. 


\section{Clinical Aspect Data}

Location

Table 3. The scar location distribution of working-age patient with keloid, hypertrophic scar, and both scars

\begin{tabular}{lcccc}
\hline Location & Keloid & $\%$ & $\begin{array}{c}\text { Hypetrophic } \\
\text { Scar }\end{array}$ & $\%$ \\
\hline Face & 10 & 11.49 & 26 & 29.55 \\
Ear & 15 & 17.24 & 2 & 2.27 \\
Neck & 3 & 3.45 & 5 & 5.68 \\
Shoulder & 6 & 6.90 & 2 & 2.27 \\
Chest & 17 & 19.54 & 5 & 5.68 \\
Abdomen & 6 & 6.90 & 2 & 2.27 \\
Arm & 14 & 16.09 & 24 & 27.27 \\
Elbow & 1 & 1.15 & 2 & 2.27 \\
Back & 4 & 4.60 & 3 & 3.41 \\
Waist & 2 & 2.30 & 2 & 2.27 \\
Tight & 1 & 1.15 & 8 & 9.09 \\
Knee & 2 & 2.30 & 3 & 3.41 \\
Leg & 6 & 6.90 & 4 & 4.55 \\
\hline Total & 87 & 100 & 88 & 100
\end{tabular}

Table 3 shows that the locations where keloid is mostly developed are 17 cases on chest (19.54\%) and the least was 1 case on the elbow and thigh, respectively $(1.15 \%)$. Meanwhile, hypertrophic scar was mostly developed on the face with 26 cases $(29.55 \%)$, and the least were 2 cases on the ears, shoulders, abdomen, elbows, and waist, respectively (2.27\%).

\section{Causes}

According to Table 4, keloid was mostly caused by trauma in 18 cases $(32.14 \%)$, and the least was chicken pox in 1 case $(1.79 \%)$. At the same time, hypertrophic scars were mostly caused by burn injury in 25 cases $(54.35 \%)$ and the least caused by acne in 1 case (2.17\%). Meanwhile, the causes of both scars developed on the same individual were caused by burn injury.

\section{Treatment}

The most chosen therapy (Table 5) for keloid was mostly corticosteroid injection on 29 cases $(37.18 \%)$ on the $1-5 \mathrm{~cm}^{2}$ scar size (18 of 29 cases), and the least was another therapy which was antihistamine ointments to treat the itchiness on 1 case (1.28\%).

Whereas in the hypertrophic scar, the most chosen therapy was excision on 20 cases (35.09\%), and the least was another therapy which was ointment and compression bandage on 4 cases $(7.02 \%)$. Patients who developed both scars chose excision surgery as their treatment.

Table 4. The distribution of causes of keloid and hypertrophic scar of working-age patient with keloid, hypetrophic scar, and both scars

\begin{tabular}{ccccccc}
\hline Causes & Keloid & $\%$ & $\begin{array}{c}\text { Hypertrophic } \\
\text { Scar }\end{array}$ & $\%$ & Both & $\%$ \\
\hline Burn Injury & 6 & 10.71 & 25 & 54.35 & 3 & 100 \\
Trauma & 18 & 32.14 & 15 & 32.61 & 0 & 0 \\
Acne & 3 & 5.36 & 1 & 2.17 & 0 & 0 \\
Chicken Pox & 1 & 1.79 & 0 & 0.00 & 0 & 0 \\
Piercing & 10 & 17.86 & 0 & 0.00 & 0 & 0 \\
Post operative & 10 & 17.86 & 3 & 6.52 & 0 & 0 \\
Idiopatic & 6 & 10.71 & 0 & 0.00 & 0 & 0 \\
Others & 2 & 3.57 & 2 & 4.35 & 0 & 0 \\
Total & 56 & 100 & 46 & 100 & 3 & 0 \\
\hline
\end{tabular}

Table 5. The treatment distribution according to the scar's size of working-age patient with keloid, hypetrophic scar, and both scars

\begin{tabular}{|c|c|c|c|c|c|c|c|c|}
\hline \multirow{2}{*}{ Type } & \multirow{2}{*}{ Treatment } & \multicolumn{5}{|c|}{ Size $\left(\mathrm{cm}^{2}\right)$} & \multirow{2}{*}{ Total } & \multirow{2}{*}{$\%$} \\
\hline & & $<1$ & $1-5$ & $6-10$ & $>10$ & No size & & \\
\hline \multirow{6}{*}{ Keloid } & $\begin{array}{c}\text { Corticosteroid } \\
\text { injection }\end{array}$ & 2 & 18 & 2 & 6 & 1 & 29 & 37.18 \\
\hline & Excision & 1 & 3 & 0 & 1 & 5 & 10 & 12.82 \\
\hline & Combination & 3 & 9 & 2 & 5 & 1 & 20 & 25.64 \\
\hline & Others & 0 & 0 & 0 & 0 & 1 & 1 & 1.28 \\
\hline & No treatment & 2 & 4 & 5 & 5 & 2 & 18 & 23.08 \\
\hline & Total & 8 & 34 & 9 & 17 & 10 & 78 & 100 \\
\hline \multirow{2}{*}{$\begin{array}{l}\text { Hypertrophic } \\
\text { Scar }\end{array}$} & $\begin{array}{l}\text { Corticosteroid } \\
\text { injection }\end{array}$ & 1 & 1 & 1 & 0 & 4 & 7 & 12.28 \\
\hline & Excision & 0 & 3 & 0 & 2 & 15 & 20 & 35.09 \\
\hline
\end{tabular}




\begin{tabular}{cccccccccc}
\hline & Combination & 0 & 2 & 2 & 2 & 6 & 12 & 21.05 \\
& Others & 0 & 1 & 1 & 0 & 2 & 4 & 7.02 \\
& No treatment & 1 & 1 & 2 & 4 & 6 & 14 & 24.56 \\
\hline \multirow{3}{*}{ Both } & Total & 2 & 8 & 6 & 8 & 32 & 57 & 100 \\
& Corticosteroid & 0 & 0 & 0 & 0 & 0 & 0 & 0 \\
& injection & Excision & 0 & 0 & 0 & 0 & 3 & 3 & 100 \\
& Combination & 0 & 0 & 0 & 0 & 0 & 0 & 0 \\
& Others & 0 & 0 & 0 & 0 & 0 & 0 & 0 \\
\hline
\end{tabular}

\section{Discussion}

\section{Demographic Aspect Data \\ Working Age}

In this study, the distribution of working-age of keloid patients and hypertrophic scar patients was mostly in the range of 17-25 years old, followed by the range of 26-35 years old. These were similar to the result of the keloid study in the Department of Dermatology and Venereology of RSUP Prof. Dr. R. D. Kandou, Manado, on January 2008-December 2010, and on $2011-2015^{3}$ of which keloid mainly occurred in the range of 15-24 years old. ${ }^{1}$

\section{Gender}

Keloid and hypertrophic scar in this study were dominated by male patients, although there was only a slight difference between male and female patients. This was similar to the theory by Shaffer in 2002 that the incidence of keloids between male and female is found equal. ${ }^{12}$ In the keloid study at LAUTECH Hospital, Nigeria, was also dominated by men. ${ }^{12}$ Meanwhile, there was also research which was dominated by women, ${ }^{1}$ such as in the Dermatology and Venereology of RSUP Prof. Dr. R. D. Kandou, Manado, on 2011-2015, with percentage of women and men of $52.69 \%$ and $47.31 \%$, respectively.

\section{Occupation}

Based on the patient's occupation, keloid and hypertrophic scar were dominated by patients as private employees, followed by traders (keloid) and students (hypertrophic scar). In the study of keloid in the Dermatology and Venereology of RSUP Prof. Dr. R. D. Kandou Manado on 2011-2015, patients as students were dominating. ${ }^{1}$ The high production of hormones, especially the androgen hormone at puberty, causes frequent acne because these hormones stimulate the oil glands to produce oil. ${ }^{13}$ Acne is one of those factors that can cause the occurrence of keloid and hypertrophic scar. ${ }^{5}$ Trauma is also susceptible to happen to students in their activities. Thus it can also be another risk factor. ${ }^{1}$

\section{Ethnicity, Tendency of Indoor or Outdoor Activity, and Skin Tones}

In this study, both keloid and hypertrophic scars were mostly developed on Javanese patients and on patients who feel dark-skinned. In addition, there were also some patient's activities of which movements caused tension of certain body areas, such as swimming, running, and playing soccer. It is supported by a theory which stated that areas of the body with high skin tension could increase the risk of developing keloids ${ }^{14}$ and other theories stated that movements which cause tension on the wound will be at high risk to develop a hypertrophic scar. ${ }^{15}$

\section{Clinical Aspect Data Location}

Based on the location, keloid most likely to occur on the chest, ears, and hands. Meanwhile, the least was on the elbows and thighs. This result was similar with the research at the Plastic Surgery Polyclinic of Dr. Soetomo General Hospital, ${ }^{16}$ Department of Dermatology and Venereology of RSUP Prof. Dr. R. D. Kandou, Manado, ${ }^{1}$ and the research in the Department of the Dermatology of Tishreen and Alassa Hospitals in Syria. ${ }^{17}$ Keloids often develop on the chest area because the chest is one of those areas with high skin tension. ${ }^{14}$ Moreover, there is a lot of dihydrotestosterone metabolism in the predilection area of keloids; one of them is the chest. This is related to the statement by Ford, et al. in 1983, about keloid tissue in which there was an increase in bonding with the androgen receptor. ${ }^{18}$

Meanwhile, the hypertrophic scars in this study mostly appear on the face, while the least location was on the ears, shoulders, elbows, abdomen, and waist. This result did not suit the theory, which stated that the predilection areas of hypertrophic scar were on the shoulder, neck, presternum, knee, and elbow. ${ }^{7}$ However, another theory states that skin contractions participate in the development of hypertrophic scars, including the facial area, especially the T zone, often undergo post-burn contractions. ${ }^{19}$ 


\section{Causes}

The causes of keloids in this study were dominated by trauma, post-surgery, and ear piercing. Keloid can also develop spontaneously in the middle of the chest area without any known injury. ${ }^{7}$ In this study, five out of six keloids in the chest area appeared spontaneously.

Furthermore, most hypertrophic scars were caused by burn injury in this study. This is supported by a theory that found similarities of excessive inflammatory responses, both in the healing process of wounds in hypertrophic scars, as well as in extensive burns. ${ }^{20}$

Then, the appearance of both pathological scars simultaneously in this study was caused by burn injury. Keloid and hypertrophic scar are skin conditions that can occur after surgery, trauma, or develop spontaneously. ${ }^{12}$

\section{Treatment Aspect Data}

In this study, the therapies options were divided into corticosteroid injection, excision, combination, others, and not treated. Combination therapy in this study consisted of a combination of non-surgical with surgical modalities and non-surgical with non-surgical modalities.

In keloids, the most chosen therapy was corticosteroid injection and combination therapy, while surgical excision therapy and other therapies were not much chosen. This was because before the therapy applied, the patients have been given information about the possibility that keloids can relapse after undergo surgical excision procedures. However, it was different from keloid therapy in a study at the Plastic Surgery Polyclinic of Dr. Soetomo Hospital in December 2008-January 2009, dominated by surgical excision therapy. ${ }^{16}$ However, the results of this study were similar to research in the Department of Dermatology and Venereology of RSUP Prof. Dr. R. D. Kandou, Manado, which also mainly chose corticosteroid injection. ${ }^{1}$

Meanwhile, hypertrophic scars were most often treated by excision. The prognosis of surgery as a therapy for hypertrophic scar is better than surgery for keloids. ${ }^{21}$ In addition, combination therapy and corticosteroid injection were also quite chosen to manage hypertrophic scars in this study. Meanwhile, patients who suffer both scars simultaneously tended to choose the excision procedure to treat them. The therapy selection for both keloid and the hypertrophic scar can be adjusted to the patient's needs, problems, and financial status. ${ }^{22}$

\section{Conclusion}

Keloid and hypertrophic scars were mostly developed at the age of 17-25 years old, dominated by male patients, and most patients work as private employees. In this case, patients who came for treatment in the Dr. Soetomo General Hospital were dominated by Javanese patients, patients who felt dark-skinned, and patients who tended to have daily indoor activities. The location of keloids was most likely to have occurred on the chest, hands, and ears. In contrast, the hypertrophic scar was mostly developed on the face area. Based on the cause, most keloids appeared due to trauma, ear piercing, and post-surgery. While hypertrophic scars and patients who developed both scars, the most common cause was burn injury. The most chosen treatments as the modality in the management of keloid were corticosteroid injection and combination treatment, which was mainly a combination of excision with corticosteroid injection. Meanwhile, patients with hypertrophic scars and patients who developed both scars tended to choose excision treatment.

\section{CONFLICT OF INTEREST}

The author stated there is no conflict of interest in this study.

\section{REFERENCES}

1. Andisi RDS, Suling PL, Kapantow MG. Profil Keloid di Poliklinik Kulit dan Kelamin RSUP Prof. Dr. R. D. Kandou Manado Periode Januari 2011-Desember 2015. J e-Clinic; 4. Epub ahead of print 2016. DOI: https://doi.org/10.35790/ecl.v4i2.14667.

2. Gefilem G. Profil Tumor Jinak Kulit di Poliklinik Kulit dan Kelamin RSUP Prof. Dr. R. D Kandou Manado Periode 2009-2011. J e-Clinic; 1. Epub ahead of print 2013.2 DOI: https://doi.org/10.35790/ecl.v1i1.3291.

3. Baker R, Urso-Baiarda F, Linge $\mathrm{C}$, et al. Cutaneous Scarring: A Clinical Review. Dermatol Res Pract 2009; 2009: 625376.

4. Nugraha A, Chaidir R, Rahayu U, et al. Factors Influencing the Occurrence of Hypertrophic Scars among Postoperative Patients in Garut, Indonesia. Belitung Nurs J 2017; 3: 23-31.

5. Ogawa R. Keloid and Hypertrophic Scars are the Result of Chronic Inflammation in the Reticular Dermis. Int $J \mathrm{Mol}$ Sci; 18. Epub ahead of print March 2017. DOI: 10.3390/ijms18030606.

6. Pontoriero A, Potami A, latì $G$, et al. Post-Operative Radiotherapy of Keloids. A 10-Years Experience of Kilovoltage Irradiation. Int J Radiat Res 2015; 13: 201-204.

7. Gauglitz GG, Korting HC, Pavicic T, et al. Hypertrophic Scarring and Keloids: Pathomechanisms and Current and Emerging Treatment Strategies. Mol Med 2011; 17: 113-125.

8. Ghazawi FM, Zargham R, Gilardino MS, et al. Insights into the Pathophysiology of Hypertrophic Scars and Keloids: How Do They Differ? Adv Skin Wound Care 2018; 31: 582-595.

9. Rabello FB, Souza CD, Farina Júnior JA. Update on Hypertrophic Scar Treatment. Clinics (Sao Paulo) 2014; 69: 565-573.

10. Mari W, Alsabri SG, Tabal N, et al. Novel Insights on Understanding of Keloid Scar: Article Review. J Am Coll Clin Wound Spec 2015; 7: 1-7.

11. Gao F-L, Jin R, Zhang L, et al. The Contribution of Melanocytes to Pathological Scar Formation during Wound Healing. Int J Clin Exp Med 2013; 6: 609613.

12. Bock O, Schmid-Ott G, Malewski P, et al. Quality of Life of Patients with Keloid and Hypertrophic Scarring. Arch Dermatol Res 2006; 297: 433-438.

13. Ravisankar P, Koushik OS, Himaja V, et al. AcneCauses and Amazing Remedial Measures for Acne. J Pharm Res; 5. 
14. Park TH, Seo SW, Kim JK, et al. Management of Chest Keloids. J Cardiothorac Surg 2011; 6: 49.

15. Mutalik S. Treatment of Keloids and Hypertrophic Scars. Indian J Dermatol Venereol Leprol 2005; 71: 3-8.

16. Pratiwi KD, Perdanakusuma D. Hubungan Antara Golongan Darah dengan Timbulnya Keloid Pascaluka. 2009; 5: 1-8.

17. Shaheen A, Khaddam J, Kesh F. Risk Factors of Keloids in Syrians. BMC Dermatol 2016; 16: 13.

18. Dyal CM. Investigation of Predictive Factors in Keloid Formation. Yale University, 1989.
19. Thompson CM, Hocking AM, Honari S, et al. Genetic Risk Factors for Hypertrophic Scar Development. J Burn Care Res 2013; 34: 477-482.

20. Nast A, Eming S, Fluhr J, et al. German S2k Guidelines for the Therapy of Pathological Scars (Hypertrophic Scars and Keloids). J Dtsch Dermatol Ges 2012; 10: 747-762.

21. Hochman B, Farkas CB, Isoldi FC, et al. Keloid and Hypertrophic Scar Distribution according to Fitzpatrick Skin Phototypes. Rev Bras Cir PlásticaThe Brazilian J Plast Surg 2012; 2727: 185-189.

22. Sasongko RH, Rahmadewi. Penatalaksanaan Skar Akne (Acne Scar Management). Berk IImu Kesehat Kulit dan Kelamin 2011; 23: 234-239. 